\title{
GAMBARAN PENGETAHUAN SIKAP DAN PERILAKU DOKTER PTT TERHADAP PANDEMI COVID-19 DI PUSKESMAS KABUPATEN BANYUASIN
}

\author{
Fonda Octarianingsih Shariff ${ }^{1}$, Festy Ladyani ${ }^{2}$, Agung Laksana Priliansyah ${ }^{3^{*}}$ \\ 1Departemen Obstetri dan Ginekologi Rumah Sakit Pertamina Bintang Amin \\ ${ }^{2}$ Dosen Fakultas Kedokteran Universitas Malahayati \\ ${ }^{3}$ Program Studi Kedokteran Fakultas Kedokteran Universitas Malahayati
}

Email Korespondensi : agunglp15@gmail.com

\section{ABSTRACT : AN OVERVIEW OF LOCUM DOCTOR'S KNOWLEDGE, ATTITUDE, AND BEHAVIOR TOWARDS THE COVID-19 PANDEMIC AT THE BANYUASIN REGENCY HEALTH CENTER}

Background : Coronavirus Disease 2019 (Covid-19) is an infectious disease caused by Severe Acute Respiratory Syndrome Coronavirus 2 (SARS-CoV-2). SARS-CoV-2 is a new virus from coronavirus class that has not been identified in humans previously. Doctors are medical personnel at the front line of dealing with the Covid-19 pandemic. The impact of Covid-19 in the world and in Indonesia is enormous, rocking the pyschological, social and economic impacts of each country. From a pandemic perspective, researcher aim to know how much impact that happen to medical personnel who are at the font line of dealing with the Covid-19 pandemic. Because for medical personnel (doctors), mental health affects decision making in the field.

Purpose : Therefore, the researchers want to see the viewpoint of the knowledge, attitudes, and behavior of a doctor towards the Covid-19 pandemic who works at the Banyuasin District Public Health Center.

Research Methods : The research method used in this research is descriptive quantitative.

Results : It is known that the distribution of respondents who have a good level of knowledge are (27\%), the level of knowledge that is quite good (43\%) and those who have a poor level of knowledge are (29.7\%); distribution of respondents who have good attitude level are (59.2\%), a fairly good attitude level are (37.8\%) and those who have poor attitude level are (2.7\%); distribution of respondents who have good behavior level are (48.6\%), fairly good behavior level are (37.8\%) and those who have poor behavior level are (13.5\%).

Conclusion : There is a fairly good level of knowledge and behavior and a good level of attitude towards PTT doctors who work at Banyuasin District Health Center about Covid-19 Pandemic.

Keywords: Locum Doctor, Covid-19 Pandemic, Knowledge, Attitude and Behavior 


\section{INTISARI : GAMBARAN PENGETAHUAN SIKAP DAN PERILAKU DOKTER PTT TERHADAP PANDEMI COVID-19 DI PUSKESMAS KABUPATEN BANYUASIN}

Latar Belakang : Coronavirus Disease 2019 (Covid-19) merupakan penyakit menular yang disebabkan oleh Severe Acute Respiratory Syndrome Coronavirus 2 (SARS CoV-2). SARS-CoV-2 merupakan virus baru dari golongan coronavirus yang belum diidentifikasi sebelumnya pada manusia. Dokter merupakan tenaga medis yang berada di garis depan dalam menangani pandemi Covid-19. Pengaruh Covid19 di dunia dan Indonesia sangat besar, sehingga mengguncang dampak psikologis, sosial dan ekonomi masing-masing negara. Dari perspektif pandemi, peneliti ingin memahami seberapa besar dampaknya terhadap tenaga medis yang berada di garis depan dalam menangani pandemi Covid-19. Sebab bagi tenaga medis (dokter), kesehatan mental sangat mempengaruhi pengambilan keputusan di lapangan.

Tujuan : Oleh sebab itu peneliti ingin melihat sebuah gambaran pengetahuan, sikap dan perilaku seorang dokter terhadap pandemi Covid-19 tepatnya yang bekerja di Pusat Kesehatan Masyarakat Kabupaten Banyuasin.

Metode Penelitian : Metode penelitian yang digunakan dalam penelitian ini adalah deskriptif kuantitatif.

Hasil : Diketahui distribusi responden yang memiliki tingkat pengetahuan baik yaitu sebanyak (27\%), tingkat pengetahuan cukup baik yaitu $(43,2 \%)$ dan yang memiliki tingkat pengetahuan kurang baik yaitu sebanyak (29,7\%); distribusi responden yang memiliki tingkat sikap baik yaitu sebanyak $(59,2 \%)$, tingkat sikap cukup baik yaitu $(37,8 \%)$ dan yang memiliki tingkat sikap kurang baik yaitu sebanyak $(2,7 \%)$; distribusi responden yang memiliki tingkat perilaku baik yaitu sebanyak $(48,6 \%)$, tingkat perilaku cukup baik yaitu $(37,8 \%)$ dan yang memiliki tingkat perilaku kurang baik yaitu sebanyak $(13,5 \%)$.

Kesimpulan : Terdapat tingkat pengetahuan dan perilaku yang cukup baik dan tingkat sikap yang baik terhadap dokter PTT yang bekerja di Puskesmas Kabupaten Banyuasin mengenai Pandemi Covid-19.

Kata Kunci : Dokter PTT, Pandemi Covid-19, Pengetahuan, Sikap dan Perilaku

\section{PENDAHULUAN}

Coronavirus Disease 2019

(Covid-19) merupakan penyakit menular yang disebabkan oleh Severe Acute Respiratory Syndrome Coronavirus 2 (SARS CoV-2). SARS CoV-2 merupakan virus baru dari golongan coronavirus yang belum diidentifikasi sebelumnya pada manusia. (Kemenkes RI, 2020).

Tanda dan gejala umum infeksi dari Covid-19 antara lain gangguan pernapasan akut seperti demam, batuk dan sesak napas. Rentan waktu antara terjadinya infeksi dan munculnya gejala (inkubasi) yaitu rata-rata 5-6 hari dengan masa terpanjangnya 14 hari.
Pada kasus Covid-19 yang berat, virus ini dapat menyebabkan gagal ginjal, pneumonia, sindrom pernapasan akut dan bahkan kematian. (Kemenkes RI, 2020).

Berdasarkan penelitian yang dilakukan RSCM, banyak petugas kesehatan yang mengalami gangguan kesehatan mental dan psikososial selama pandemi Covid-19. Di RSCM sendiri, petugas kesehatan mengalami takut tertular, takut menulari anggota keluarga di rumah, kecemasan terhadap alat pelindung diri serta perkembangan kasus yang semakin meningkat (PERSI, 2020).

Data yang dihimpun oleh tim Pandemic Talks menunjukkan angka 
kematian dokter di Indonesia meningkat signifikan, meski turun $71 \%$ pada Mei, meningkat pesat menjadi $150 \%$ pada Juni, dan $200 \%$ pada Juli.

Dari perspektif pandemi, peneliti ingin memahami seberapa besar dampaknya terhadap tenaga medis (dokter) yang berada di garis depan dalam menangani pandemi Covid-19. Sebab bagi tenaga medis (dokter), kesehatan mental sangat mempengaruhi pengambilan keputusan di lapangan. Sehingga mempengaruhi pengetahuan, sikap dan perilaku seorang dokter dalam menghadapi pandemi Covid-19.

\section{METODELOGI}

Metode penelitian yang digunakan dalam penelitian ini adalah deskriptif kuantitatif. Penelitian ini menggunakan data primer kuesioner sebagai alat ukur. Data yang diperoleh dinyatakan secara deskriptif kuantitatif dengan perhitungan mengukur tingkatan pengetahuan, sikap dan perilaku dokter PTT terhadap Pandemi Covid19.

\section{HASIL}

Distribusi frekuensi responden berdasarkan karakteristik dokter PTT yang bekerja di Puskesmas Kabupaten Banyuasin. Proporsi responden berdasarkan jenis kelamin pada penelitian ini didapatkan responden yang berjenis kelamin perempuan yaitu 23 responden $(63,2 \%)$, sedangkan responden yang berjenis kelamin laki-laki sebanyak 14 responden (37,8\%). Distribusi responden menurut usia pada tabel 1 didapatkan usia 20-30 tahun sebanyak 19 responden $(51,4 \%)$, usia 31-40 tahun 15 responden (41.5\%), dan usia $>40$ tahun sebanyak 3 responden $(8,1 \%)$.

Distribusi responden menurut asal perguruan tinggi dari 37 responden hanya 5 responden $(13,5 \%)$ yang merupakan lulusan perguruan tinggi negeri, sedangkan 32 responden $(86,5 \%)$ merupakan lulusan perguruan tinggi swasta. Distribusi responden menurut pengalaman kerja sebagai dokter PTT yang bekerja $<1$ tahun yaitu 9 responden (24,3\%), bekerja 1-2 tahun sebanyak 12 responden $(32,4 \%)$ dan bekerja $>3$ tahun sebanyak 16 responden (43.2\%).

Update informasi Covid-19 adalah kegiatan memperbarui informasi terkini tentang Covid-19 seperti seminar dan pelatihan. Pada distribusi data responden yang tidak pernah mengikuti kegiatan seminar atau pelatihan sebanyak 12 responden $(32,4 \%)$ sedangkan responden yang mengikuti 1-2x kegiatan tersebut sebanyak 24 responden $(64,9 \%)$ dan responden yang mengikuti $>3 x$ kegiatan seminar atau pelatihan Covid-19 sebanyak 1 responden $(2,7 \%)$.

Tabel 1. Karakteristik Responden

\begin{tabular}{ccc} 
Jenis Kelamin & $\begin{array}{c}\text { Frekuensi } \\
\text { (f) }\end{array}$ & $\begin{array}{c}\text { Persentase } \\
\text { (\%) }\end{array}$ \\
\hline Laki-Laki & 14 & $37.8 \%$ \\
Perempuan & 23 & $63.2 \%$ \\
Total & $\mathbf{3 7}$ & $\mathbf{1 0 0 \%}$ \\
\hline Umur/Usia & $\begin{array}{c}\text { Frekuensi } \\
\text { (f) }\end{array}$ & $\begin{array}{c}\text { Persentase } \\
\text { (\%) }\end{array}$ \\
\hline $20-30$ & 19 & $51.4 \%$ \\
$31-40$ & 15 & $41.5 \%$ \\
$>40$ & 3 & $8.1 \%$
\end{tabular}




\begin{tabular}{ccc} 
Total & $\mathbf{3 7}$ & $\mathbf{1 0 0 \%}$ \\
\hline $\begin{array}{c}\text { Asal Perguruan } \\
\text { Tinggi }\end{array}$ & $\begin{array}{c}\text { Frekuensi } \\
\text { (f) }\end{array}$ & $\begin{array}{c}\text { Persentase } \\
\text { (\%) }\end{array}$ \\
\hline $\begin{array}{c}\text { Perguruan Tinggi } \\
\text { Negeri }\end{array}$ & 5 & $13.5 \%$ \\
$\begin{array}{c}\text { Perguruan Tinggi } \\
\text { Swasta }\end{array}$ & 32 & $86.5 \%$ \\
Total & $\mathbf{3 7}$ & $\mathbf{1 0 0 \%}$ \\
\hline Pengalaman & $\begin{array}{c}\text { Frekuensi } \\
\text { Kerja }\end{array}$ & $\begin{array}{c}\text { Persentase } \\
\text { (f) }\end{array}$ \\
\hline <1 Tahun & 9 & $24.3 \%$ \\
1-2 Tahun & 12 & $32.4 \%$ \\
$>3$ Tahun & 16 & $43.2 \%$ \\
Total & $\mathbf{3 7}$ & $\mathbf{1 0 0 \%}$ \\
\hline Update & $\begin{array}{c}\text { Frekuensi } \\
\text { Informasi }\end{array}$ & $\begin{array}{c}\text { Persentase } \\
\text { (f) }\end{array}$ \\
\hline Tidak Pernah & 12 & $32.4 \%$ \\
1-2x & 24 & $64.9 \%$ \\
$>3 x$ & 1 & $2.7 \%$ \\
Total & $\mathbf{3 7}$ & $\mathbf{1 0 0 \%}$ \\
\hline
\end{tabular}

Berdasarkan tabel dibawah ini, tingkat pengetahuan responden terhadap pandemi Covid-19, didapatkan 10 responden $(27 \%)$ memiliki tingkat pengetahuan baik, tingkat pengetahuan cukup baik 16 responden $(43,2 \%)$ dan yang memiliki tingkat pengetahuan kurang baik terdapat 11 responden $(29,7 \%)$.

Tabel 2 Kategori Tingkat Pengetahuan Responden Terhadap Pandemi Covid19

\begin{tabular}{ccc}
\hline Pengetahuan & Frekuensi (f) & Persentase (\%) \\
\hline Baik & 10 & $27.0 \%$ \\
Cukup Baik & 16 & $43.2 \%$ \\
Kurang Baik & 11 & $29.7 \%$ \\
\hline Total & $\mathbf{3 7}$ & $\mathbf{1 0 0} \%$ \\
\hline
\end{tabular}

Berdasarkan tabel 3 didapatkan kategori sikap responden terhadap pandemi Covid-19 yaitu 22 responden $(59,5 \%)$ memiliki tingkat sikap baik, yang memiliki tingkat

sikap cukup baik 14 responden $(37,8 \%)$ dan yang memiliki tingkat sikap kurang baik hanya 1 responden $(2,7 \%)$.

Tabel 3 Kategori Tingkat Sikap Responden Terhadap Pandemi Covid-19

\begin{tabular}{ccc}
\hline Sikap & Frekuensi (f) & Persentase (\%) \\
\hline Baik & 22 & $59.5 \%$ \\
Cukup Baik & 14 & $37.8 \%$ \\
Kurang Baik & 1 & $2.7 \%$ \\
\hline Total & 37 & $100 \%$ \\
\hline
\end{tabular}

Berdasarkan tabel 4 diperoleh kategori tingkat perilaku responden terhadap pandemi Covid-19 yaitu 18 responden $(48,6 \%)$ yang memiliki 
tingkat perilaku baik, tingkat perilaku cukup baik 14 responden perilaku kurang baik 5 responden $(37,8 \%)$ dan yang memiliki tingkat $(13,5 \%)$.

Tabel 4 Kategori Tingkat Perilaku Responden Terhadap Pandemi Covid-19

\begin{tabular}{ccc}
\hline Perilaku & Frekuensi (f) & Persentase (\%) \\
\hline Baik & 18 & $48.6 \%$ \\
Cukup Baik & 14 & $37.8 \%$ \\
Kurang Baik & 5 & $13.5 \%$ \\
\hline Total & 37 & $100 \%$ \\
\hline
\end{tabular}

Skor kumulatif dari variabel pengetahuan, sikap dan perilaku responden dikategorikan menjadi 3 kelompok, yaitu : Baik : 76100\%, Cukup baik : 56-75\%, dan Kurang baik : $<56 \%$. Berdasarkan Tabel 4.9 hasil jawaban kuesioner pengetahuan mengenai Covid-19 didapatkan 1 pertanyaan tertinggi dengan persentase $>76 \%$ yang dijawab dengan benar yaitu no 1 $(100 \%)$ sedangkan pada pertanyaan dengan persentase jawaban $56-75 \%$ pada no $2(75,7 \%)$ dan no $3(62,2 \%)$ dan jawaban responden dengan persentase terendah $<56 \%$ pada no 4 $(43,2 \%)$, no $5(32,4 \%)$ dan no 6 $(18,9 \%)$, sehingga rata-rata responden memiliki pengetahuan yang cukup baik. Hasil jawaban kuesioner sikap mengenai Covid-19 berdasarkan tabel dibawah ini didapatkan 2 pertanyaan dengan persentase tertinggi yaitu $>76 \%$ yang dijawab benar oleh responden pada no $1(94,6 \%)$ dan no $2(94,6 \%)$ dan rata-rata jawaban pada responden mengenai sikap terhadap Covid-19 memiliki persentase $56-75 \%$ sehingga responden dikategorikan baik. Pada perilaku responden mengenai Covid19 didapatkan 2 pertanyaan dengan jawaban benar teratas dengan persentase $>76 \%$ yaitu pada no 1 $(92,9 \%)$, no $2(89,2 \%)$ dan pertanyaan yang memiliki nilai $56-75 \%$ pada no 3 $(75,7 \%)$, no $4(75,7)$, no $5(62,2 \%)$ dan no $6(59,5 \%)$ sehingga rata-rata perilaku responden mengenai Covid19 dikategorikan cukup baik.

Tabel 5 Kategori Tingkat Perilaku Responden Terhadap Pandemi Covid-19

\begin{tabular}{|c|c|c|}
\hline $\begin{array}{l}\mathbf{N} \\
\mathbf{0}\end{array}$ & Pernyataan atau Pertanyaan & (\%) \\
\hline \multicolumn{3}{|c|}{$\begin{array}{ll}\text { Pengetahuan } \\
\end{array}$} \\
\hline 1 & $\begin{array}{l}\text { Face shield tanpa menggunakan masker dapat melindungi dengan } \\
\text { aman dari penularan Covid-19? } \\
\text { Apakah anda tahu pedoman pencegahan dan pengendalian Covid- }\end{array}$ & $100 \%$ \\
\hline 2 & $\begin{array}{l}19 \text { yang dikeluarkan oleh Kemenkes RI telah di revisi sebanyak } 5 x \\
\text { ? }\end{array}$ & $75,7 \%$ \\
\hline 3 & Apakah anda tahu Covid-19 merupakan standar kompetensi 4A ? & $62,2 \%$ \\
\hline 4 & Apakah angka kasus positif terbanyak di Asia ada di Indonesia ? & $43,2 \%$ \\
\hline 5 & Apakah ukuran virus Covid-19 1-5um? & $32,4 \%$ \\
\hline \multirow[t]{2}{*}{6} & $\begin{array}{l}\text { Orang yang sering beraktivitas olahraga aman dari penularan } \\
\text { penyakit Covid-19? }\end{array}$ & $18,9 \%$ \\
\hline & Rata-Rata Pengetahuan & $65,7 \%$ \\
\hline
\end{tabular}


1 Bagaimana menurut anda, jika anda mendiskusikan kepada pasien jika di rumah tidak perlu sering mencuci tangan.

Bagaimana menurut anda, pegawai yang bukan bagian tenaga

2 kesehatan juga menggunakan APD di puskesmas anda.

3 Bagaimana menurut anda, apakah seorang dokter tidak wajib mencuci tangan pada saat di rumah sehabis pulang kerja.

Jika anda sedang berkunjung ke suatu wilayah yang bukan wilayah

4 kerja anda dan ada pasien dengan keluhan batuk dan sesak , apakah anda menyuruh orang tersebut ke faskes terdekat.

5 Bagaimana menurut anda, cukup minum obat warung jika keluhan batuk ringan

6 Ketika ada pasien terkonfirmasi positif, apa anda akan mengawasi pasien sampai sembuh.

7 Bagaimana menurut anda, jika pasien darurat datang ke puskes anda tidak menggunakan masker, anda mengusirnya.

8 Bagaimana menurut anda, bahwa orang yang menderita gejala covid ringan tidak perlu di obati karena bisa sembuh sendiri. Rata-Rata Sikap

\begin{tabular}{lll}
\hline & \multicolumn{1}{c}{ Perilaku } & \\
\hline 1 & $\begin{array}{l}\text { Apakah anda sering mengonsumsi vitamin beberapa bulan ini } \\
\text { selama pandemi Covid-19. }\end{array}$ & $91,9 \%$ \\
2 & $\begin{array}{l}\text { Apakah tidur anda 6-8 jam dalam sehari selama pandemi Covid- } \\
19 .\end{array}$ & $89,2 \%$ \\
3 & Apa anda berolahraga/aktifitas seperti biasa saat pandemi ini. \\
4 & $\begin{array}{l}\text { Apakah anda menghindari berkomunikasi pada orang yang tidak } \\
\text { saya kenal selama pandemi Covid-19. }\end{array}$ & $75,7 \%$ \\
5 & $\begin{array}{l}\text { Apakah anda sering menyentuh area wajah seperti mata, hidung } \\
\text { dan mulut dalam keadaan tangan belum dicuci. }\end{array}$ & $62,2 \%$ \\
6 & $\begin{array}{l}\text { Apakah anda sering berpergian ke luar rumah selama pandemi } \\
\text { Covid-19. }\end{array}$ & $59,5 \%$ \\
Rata-Rata Perilaku & $75,6 \%$ \\
\hline
\end{tabular}

\section{PEMBAHASAN}

Berdasarkan data-data yang diperoleh dari hasil penelitian yang dilakukan pada bulan Desember 2020, maka penelitian ini akan dibahas sebagai berikut.

Dari hasil pengolahan data menggunakan IBM SPSS 26.0. Pengetahuan responden mengenai Covid-19 pada penelitian ini cukup baik. Sebanyak 16 responden memiliki tingkat pengetahuan yang cukup dan 10 responden memiliki tingkat pengetahuan baik. Sedangkan sikap responden mengenai Covid-19 pada penelitian ini mendapatkan kategori baik. Rata-rata responden memiliki sikap yang baik yaitu 22 responden, sikap yang cukup baik yaitu 14 responden dan hanya 1 responden yang memiliki sikap kurang baik. Pada perilaku responden mengenai Covid-19 didapatkan responden memiliki perilaku yang baik dilihat pada tabel 4 dengan persentase yaitu responden yang memiliki perilaku baik yaitu berjumlah 18 responden, responden yang memiliki perilaku cukup baik terdiri dari 14 responden dan hanya 5 responden yang memiliki perilaku kurang baik.

Penelitian ini didominasi oleh responden berjenis kelamin perempuan dibandingkan berjenis 
kelamin laki-laki. Hal ini menunjukan secara umum responden perempuan memiliki pengetahuan lebih baik dari pada laki-laki. Perempuan secara psikologis lebih termotivasi dan lebih rajin dalam hal belajar dan bekerja dari pada laki-laki. Hal ini yang membuat prestasi akademik perempuan lebih baik dibandingkan laki-laki. (Awaliyah, 2011). Sedangkan yang mempengaruhi tingkat sikap responden itu sendiri adalah perempuan, karena perempuan memiliki sikap yang lebih baik daripada laki-laki. Hal ini mungkin disebabkan karena perempuan lebih lembut dalam bersikap, lebih pintar membaca emosi dan lebih peka terhadap situasi dan perasaan orang lain. (Rahman, 2009). Hal yang mempengaruhi perilaku responden jika dilihat dari sisi jenis kelamin. Dilihat dari tabel 1 pada penelitian ini didominasi oleh kaum perempuan dibandingkan kaum laki-laki. Perempuan dari segi psikologis sosial lebih cenderung menunjukan perilaku baik dan menolong dibandingkan dengan lakilaki. (Sari, 2011).

Pengetahuan, sikap dan perilaku jika dilihat dari sudut pandang usia. Berdasarkan distribusi data rata-rata responden pada penelitian ini, didominasi oleh responden yang berusia 20-30 tahun dan usia 31-40 tahun dibandingkan responden yang berusia $>40$ tahun. Dalam survei APJII terungkap bahwa pengguna internet yang paling banyak di Indonesia adalah mereka yang berusia antara 19-34 tahun yakni mencapai 49,5\%. (survei APJII, 2017). Sebuah penelitian di Pakistan yang menilai pengetahuan, sikap, praktik dan hambatan tenaga kesehatan selama menghadapi Covid-19. Didapatkan juga pada usia <30 tahun yaitu $91,6 \%$ tenaga kesehatan disana memiliki persentasi pengetahuan yang baik. (Saqlain et al, 2020). Hal tersebut disebabkan penggunaan teknologi internet dalam mengakses media massa tentang informasi Covid-19 sangat masif sehingga pada usai 20-30 tahun dan 31-40 tahun penggunaan teknologi tersebut sangat produktif dari pada usia $>40$ tahun.

Sedangkan yang mempengaruhi dari pada sikap responden yaitu pengetahuan. Dilihat dari komponen kognitif yang merupakan representasi apa yang dipercayai oleh individu pemilik sikap. Komponen Kognitif (Perceptual Component), yaitu komponen yang berkaitan dengan pengetahuan, pandangan dan keyakinan. (Azwar, 2003). Hal tersebut sesuai dengan usia responden yang masih produktif dalam mendapatkan akses informasi Covid-19 di era teknologi digital. Sehingga pengetahuan tersebut mempengaruhi sikap terhadap responden.

Jika dilihat dari perilaku responden yang memiliki usia 20-30 tahun selain memiliki akses ke teknologi internet yang mudah, disisi lain responden memiliki pengetahuan dan sikap yang baik. Pada usia 20-30 tahun yang merupakan usia produktif dalam mengakses dan menggali informasi sehingga memiliki perilaku yang baik. Menurut Wawan dan Dewi (2010), Semakin bertambahnya usia, pengalaman dan tingkat kematangan seseorang juga bertambah sehingga ilmu dan pengalaman yang didapatkan lebih banyak dan mempengaruhi perilaku orang itu sendiri.

Faktor lain yang mempengaruhi pengetahuan, sikap dan perilaku responden pada penelitian ini adalah pengalaman kerja. Pada tabel 1 responden pada penelitian ini memiliki rata-rata pengalaman 1-2 tahun dan $>3$ tahun. Pengalaman bekerja mempengaruhi pengetahuan, sikap dan perilaku terhadap suatu objek tertentu. Pengalaman kerja adalah tingkat 
penguasaan pengetahuan serta keterampilan seseorang dalam pekerjaannya yang dapat diukur dari masa kerja dan dari tingkat pengetahuan serta keterampilan yang dimilikinya. (Alias dan Serling, 2018). Orang yang mempunyai pengalaman akan selalu lebih pandai dalam menyikapi dari segala hal daripada mereka yang sama sekali tidak memiliki pengalaman. (Gibson, 2011). Dari persentase tabel 1 didapatkan tingkat perilaku lebih banyak dimiliki oleh responden yang memiliki pengalaman kerja > 3 tahun. Hal tersebut sesuai dengan teori dari Wawan dan Dewi (2010), semakin bertambahnya usia, pengalaman dan tingkat kematangan seseorang juga bertambah sehingga ilmu dan pengalaman yang didapatkan lebih banyak.

Hal yang mempengaruhi pengetahuan, sikap dan perilaku responden berdasarkan update informasi Covid-19. Pada penelitian ini didapatkan responden yang tidak pernah mengikuti kegiatan seminar atau pelatihan sebanyak 12 orang dan mengikuti kegiatan 1-2x 24 orang dan

\section{KESIMPULAN}

Berdasarkan hasil penelitian gambaran pengetahuan, sikap dan perilaku dokter PTT terhadap pandemi Covid-19 di Puskesmas Kabupaten Banyuasin disimpulkan bahwa :

1. Diketahui distribusi responden yang memiliki tingkat pengetahuan baik yaitu sebanyak (27\%), tingkat pengetahuan yang cukup baik yaitu $(43,2 \%)$ dan yang memiliki tingkat pengetahuan kurang baik yaitu sebanyak $(29,7 \%)$.

\section{DAFTAR PUSTAKA}

Andriani, D.A. (2020). Pengaruh Disiplin Kerja, Pengalaman Kerja dan Pendidikan Karyawan Terhadap Promosi Jabatan mengikuti kegiatan $>3 x$ hanya 1 orang.

Menurut Maulana, informasi yang diperoleh seseorang akan diproses dan menghasilkan pengetahuan. (Maulana, 2009). Semakin sering seseorang mendapatkan informasi maka akan semakin meningkat pengetahuannya dan akan mempengaruhi sikap dan perilakunya. (Sirait, 2013). Pada penelitian ini responden memiliki pengetahuan yang cukup walaupun tidak pernah mengikuti seminar atau pelatihan, hal tersebut dikarenakan faktor media penerimaan informasi Covid-19 yang sangat luas dan tanpa adanya kegiatan seminar atau pelatihan, informasi pengetahuan tentang Covid-19 juga bisa didapat. Sebuah penelitian di Jordan University menunjukan, sumbersumber pengetahuan tentang Covid19 yang didapat selama penelitian tersebut yaitu media sosial $34 \%$, WHO $19,9 \%$, TV $17,6 \%$, Internet $13 \%$, Kementrian Kesehatan 10,1\% dan informasi teman 5,4\%. (Alzoubi et al, 2020).

2. Diketahui distribusi responden yang memiliki tingkat sikap baik yaitu sebanyak (59,2\%), tingkat sikap cukup baik yaitu $(37,8 \%)$ dan yang memiliki tingkat sikap kurang baik yaitu sebanyak $(2,7 \%)$.

3. Diketahui distribusi responden yang memiliki tingkat perilaku baik yaitu sebanyak $(48,6 \%)$, tingkat perilaku cukup baik yaitu $(37,8 \%)$ dan yang memiliki tingkat perilaku kurang baik yaitu sebanyak $(13,5 \%)$.

pada Swalayan Embah;E Murah Ponorogo, Madiun Dan Magetan. Jurnal Ekonomi, Manajemen dan Akuntansi. Vol 
4 (1) : ISSN :25987496, E- ISSN : 25990578

Alfaqinisa, R. (2015). Hubungan Antara Tingkat Pengetahuan, Sikap, Dan Perilaku Orang Tua Tentang Pneumonia Dengan Tingkat Kekambuhan Pneumonia Pada Balita Di Wilayah Kerja Puskesmas Ngesrep Kota Semarang. Skripsi.

Alias dan Serang, S. (2018). Pengaruh Pengetahuan, Sikap Kerja Dan Pengalaman Kerja Terhadap Kinerja Karyawan. Paradoks Jurnal Ilmu Ekonomi. Vol 1 (1) : e-ISSN : 2622-6383.

Alzoubi, H., Alnawaiseh, N., AlMnayyis, A., Lubad, M. A., Aqel, A., \& Al-Shagahin, H. 2020. COVID-19-knowledge, attitude and practice among medical and non-medical University Students in Jordan. J Pure Appl Microbiol, 14(1), 17-24.

Anwar, S., Salsabila, I., Sofyan, R dan Amna, Z. (2019). Laki-Laki Atau Perempuan, Siapa Yang Lebih Cerdas Dalam Proses Belajar? Sebuah Bukti Dari Pendekatan Analisis Survival. Jurnal Psikologi. Vol 18 (2) : 281-296

Asosiasi Penyelenggara Internet Indonesia. (2017). Penetrasi dan Perilaku Penggunaan Internet Indonesia. Infografis Hasil Survey 2017. Indonesia

Kementerian Kesehatan Republik Indonesia. (2020). Pedoman Pencegahan Dan Pengendalian Coronavirus Disesase (Covid-19) Revisi-5. Kementerian Kesehatan Republik Indonesia. Jakarta.

Octavianus, W.R. dan Adolfina. (2018). Pengaruh Pengalaman Kerja Dan Pelatihan Kerja Terhadap Kinerja Karyawan PT. Telkom Indonesia Cabang Manado. Jurnal EMBA. Vol 6(3):1758-1767.
Perhimpunan Rumah Sakit Seluruh Indonesia (PERSI). (2020). Webinar PERSI: Hadapi Covid19, Nakes pun Rentan Alami Stres, Solusinya Sikap Positif dan Saling Dukung.

Rosyanti, L., dan Hadi, I. (2020). Dampak Psikologis dalam Memberikan Perawatan dan Layanan Kesehatan Pasien COVID-19 pada Tenaga Profesional Kesehatan. HIJP : Health Information Jurnal Penelitian. Vol 12 (1) : p-ISSN: 2083-0840|e-ISSN: 2622-5905

Sari, D. (2011). Gambaran Pengetahuan, Sikap Dan Perilaku Mengenai Hiv/Aids Pada Mahasiswa Program Studi Pendidikan Dokter Universitas Tanjungpura. Naskah Publikasi. Program Studi Pendidikan Dokter Fakultas Kedokteran Universitas Tanjungpura Pontianak. Pontianak

Saqlain, M., Munir, M. M., Rehman, S. U., Gulzar, A., Naz, S., Ahmed, Z., and Mashhood, M.. 2020. Knowledge, attitude, practice and perceived barriers among healthcare workers regarding COVID-19: a cross-sectional survey from Pakistan. Journal of Hospital Infection, 105(3), 419-423.

Sirait, N.A.J., Rustina, Y., dan Waluyanti, F, T. (2013). Pemberian Informasi Meningkatkan Pengetahuan, Sikap Dan Keterampilan Orang Tua Dalam Penanganan Demam Pada Anak. Jurnal Keperawatan Indonesia.

Sugiono. (2016). Metode Penelitian Kuantitatif, Kualitatif dan $R \& D$. Cetakan ke-23. Alfabeta. Bandung.

Wawan, A. dan M. Dewi. (2010). Teori \& Pengukuran Pengetahuan, Sikap, dan Perilaku Manusia Dilengkapi Contoh Kuisioner. Nuha Medika. Yogyakarta. 